\title{
Explosive power of lower limbs in rhythmic gymnastics athletes in different competitive levels
}

CDD. 20.ed. 796.41

http://dx.doi.org/10.1590/1807-55092016000100041
Amanda Batista SANTOS*

Eunice LEBRE*

Lurdes Ávila CARVALHO*
*Faculdade de Desporto, Universidade do Porto, Porto, Portugal.

\begin{abstract}
The explosive power in Rhythmic Gymnastics shows itself in the great majority of movements and elements performed by the gymnasts, particularly in the jumps, which are essential corporal movements in this sport. The training directed to the development of jumping capacity presents a large quantity of exercises which aim to improve muscular power in the lower limbs and therefore the impulsion capacity. The vertical impulsion is an important measure used to calculate the explosive power of the lower limbs and is directly connected to the success that the gymnast will be able to achieve. Therefore, the aim of this study is to evaluate the height of two jumps in the RG (stag jump and Cossack jump) in contact mat Ergojump, which calculates the jump height in connection with the flight timing, executed by national level junior gymnasts and to compare them to the results of the Junior National Team - in total 30 junior gymnasts with $13.73 \pm 0.17$ years old. Furthermore, to compare the levels of explosive power of preferred lower limb (PLL) and non-preferred lower limb (NPLL) of all gymnasts in the study, in order to verify eventual functional asymmetries. For the statistical analysis we used Parametric Tests ( $\mathrm{t}$ Test) and Nonparametric (Mann-Whitney Test and Wilcoxon Test). The gymnasts of the National Team achieved superior marks in $33.3 \%$ of the tests and $83.3 \%$ of the gymnasts of our sample did not present explosive power asymmetries. We conclude that the gymnasts of the National Team did not show the expected superiority in the tests, and the most of gymnasts presented a harmonious development of explosive power for both lower limbs, since they did not show functional asymmetries.
\end{abstract}

KEY WoRDS: Explosive power; Jumps; Vertical impulsion; Rhythmic gymnastics; Lower limbs.

\section{Introduction}

In Rhythmic Gymnastics, the gymnast must present powerful muscular groups, to achieve a good performance in the training and competition routines ${ }^{1}$. However, "powerful" cannot be interpreted as "bulky", because the RG athletes present a longilineal muscular structure, fortified and elastic ${ }^{2}$ which allows the lightness and loveliness movements ${ }^{3}$. The gymnasts are usually thin and don't present muscular mass definition in excess, once the muscular hypertrophy is not aesthetic in this sport ${ }^{3-4}$.

The gymnast depends on the strength capacity for technical performance mastery. According to BADILLO and AyesTÁRAN ${ }^{5}$, the technical failures are often wrongly explained by lack of coordination, ability or training, the authors said that they happen by lack of strength in the muscular groups. According to the authors is necessary for an adequate performance of the movements.

For the public often the strength is not considered a relevant motor capacity in $\mathrm{RG}$, since the gymnasts are associated to a high flexibility level only. However the strength in RG is part of the great majority of movements performed by the gymnasts, with or without apparatus. The correct technical performance, with the necessary range and intensity are only possible if a high level of strength development is achieved ${ }^{6}$. Therefore is unquestionable that the strength represents a determinant role to the high performances in this sport. RG requires gymnasts with high flexibility 
and a good connexion between strength and flexibility for high quality performance?

The explosive power is considered the main component of strength in $\mathrm{RG}^{8}$, and several skills, as jumping or plyometric exercises, have been used to improve this capacity'. According to KraEmer and NewTON ${ }^{10}$, the explosive muscular power is the ability to generate muscular work in a short time, and the rate of force production is the basis for most sport actions. The development of this motor skills allied to the technical skill is the base for a good performance of movements and specific elements of RG. In this sport we can refer the jumps as an example of the lower limbs (LL) explosive power and the throw of the apparatus as the explosive power of the upper limbs (UL) .

In $R G$ the jumps are the foundation body elements in training and in competition routines. For Petry ${ }^{11}$ these are considered as the body elements more difficult to perform in a correct way. The jump must synchronize the movements of legs, arms, trunk, head and still coordinated with the handling the apparatus. In this sense performing it in a correct way becomes a difficult task.

The jump is evaluated by qualitative methods when it is observed and considered valid or not $^{11}$. The FIG Code of Points ${ }^{12}$ determines that the jump difficulties must have the following characteristics: a defined and fixed shape during the flight and a height (elevation) sufficient to show the corresponding shape. This group of elements is valorized according to two main aspects: the range, as a result of the elevation capacity, and to its shape, achieved by the physical segment positioning during the different phases - impulsion, aerial and reception ${ }^{13}$. The take-off can be done with one or both feet, depending of the jump. The arms movement is made at the same time that the athlete flexes the leg or both legs on the take-off ${ }^{14}$. The trunk is kept vertically for vertical jumps and slightly ahead when the gymnast performed a leap. The shoulders must be kept low and slightly behind during the take-off. The arms movement helps the

\section{Method}

The explosive power of LL was analyzed in this study through the evaluation of two basic jumps in RG. The main purpose of the jump selection was the approach of explosive power evaluation to specific jump used in the sport, in order to guarantee a result take-off action, allowing a jump with a higher fly time, and the stability of the body ${ }^{6}$.

The fly phase depends on the quality of the takeoff; the duration of the flight depends directly on the power and jump height. During the jumps the gymnast has to achieve the highest possible height, associated with the performance of the movement with extreme lightness and in an easy way. The higher the flight during the jump, the greater are the possibilities to succeed in fixing the shape desired efficiently and therefore more guarantees for its validation by the judges ${ }^{3,14}$. It is also important the performance of all body, through a good position of the body segments. Therefore is necessary to perform the jumps maintaining a fix and wide shape, according to the requirements of the Code of Points ${ }^{3}$.

The training oriented to the development of jumping capacity includes a wide variety of exercises to increase the degree of LL muscular power and therefore the take-off power. The vertical impulsion is an important measure used to calculate the LL explosive power and is directly connected to the success that the gymnast will be able to achieve ${ }^{15}$. According PiAzza et al. ${ }^{16}$, motor performance skill tests such as vertical jumps are commonly used to assess changes in muscular strength and power. During a routine the gymnasts have to perform a lot of jumps, associated to rotations, lift flights in groups' competition, also with a perfect execution ${ }^{15}$.

The aim of this study is to evaluate the height in two basic jumps in the RG executed by national level junior gymnasts and to compare them to the results of the Junior National Team. Furthermore, to compare the levels of explosive power of preferred lower limb (PLL) and non-preferred lower limb (NPLL) of all gymnasts in the study, in order to verify eventual functional asymmetries.

The hypothesis of the study is that the elite gymnasts (National Team) have superior level of explosive power in all jumps evaluated than the national level gymnasts, and is expected that the gymnasts of sample have functional asymmetries.

close to reality. We analyze the stag jump height with 2 feet take-off start and Cossack jump performed with PLL forward (PLL take-off), followed by NPLL forward (PLL take-off) with the purpose to compare the height of the jump performed with different LL. 
As the selected jumps must be executed the same way as the competition routine, the arms movement was allowed considering that this action could change the results of the tests. Usually the jump tests are evaluated with the hands on the hips or arms above the head with the aim to isolate the LL muscles and reduce the effect of variations in arms movement coordination.

The jumps evaluation were carried out on the contact platform - Ergojump (Digitime 1000, Digest Finland) which is a mat made out by electronic circuits connected to a software which calculates the jump height through flight time ${ }^{17}$. The results are registered in centimeters and kept in the computer - height value and time of jump flight. Three repetitions were made and the final result is represented by the best value obtained. To validate the result of each repetition, the jumps must be executed according to the Code of Points rules ${ }^{18}$.

The jumps were performed according to the main characteristics of the Counter Movement Jump (CMJ): the athlete is allowed to perform the eccentric phase followed by the concentric movement. In this study the arms movement was authorized and the initial position of the LL is determined by the own characteristics of each jump preparation ${ }^{19}$.

This type of evaluation may be used in the diagnosis and control of training load in different sports ${ }^{20}$. In the present study we use this evaluation to determine de explosive power of LL (vertical impulsion).

\section{Sample}

This study concerns the analysis of 30 junior gymnasts with $13.73 \pm 0.17$ years old, which participated in national competitions in the season 2010/2011. In this sample we have 5 gymnasts which are part of the National Team.

The sample was divided in two groups: high level (National Team gymnasts) and national level (other all gymnasts).

The tests were applied in competitive environment in March and April 2011.

The parents of the gymnasts gave their written consent for the study before data collection. The study was approved by the University of Porto and all procedures were in accordance with the Helsinki declaration. Portugal Gymnastics Federation has been informed and authorized the study.

\section{Jump}

Test 1: Stag Jump (FIGURE 1).

Objective: Measurement of Stag Jump with 2 feet take-off.

Equipment: Ergojump.

Measurement: the device shows the jump height in centimeters $(\mathrm{cm})$ - The athlete performed the same jump three times and the final result will be the best result achieved.

Action: Start outside the mat, the gymnast performs a step towards inside, puts the LL together immediately and performs the stag jump. The gymnast chooses the LL preferable for jumping.

Requirements: Evaluation of the jump according to Code of Points requirements ${ }^{21}$.

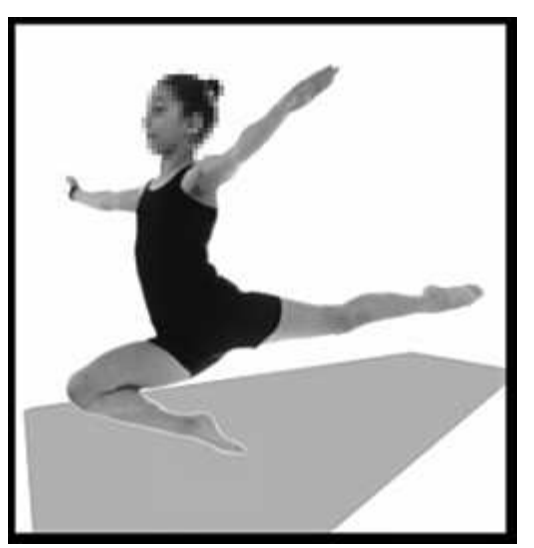

FIGURE 1 - Jump shape corresponding to test 1: Stag Jump.

Tests 2 and 3: Cossack Jump (FIGURE 2).

Objective: measurement of height for Cossack Jump performed with PLL forward (NPLL takeoff) - Test 2, followed by NPLL forward (PLL take-off) - Test 3.

Equipment: Ergojump.

Measurement: The device shows the jump height in centimeters $(\mathrm{cm})$ - The athlete performed the jump three times with each LL and the final result will be the best result achieved.

Action: Start outside the mat, the gymnast performs a step towards the jump entering the mat, without any type of preparation.

Requirements: Evaluation of the jump according to Code of Points requirements ${ }^{21}$. 


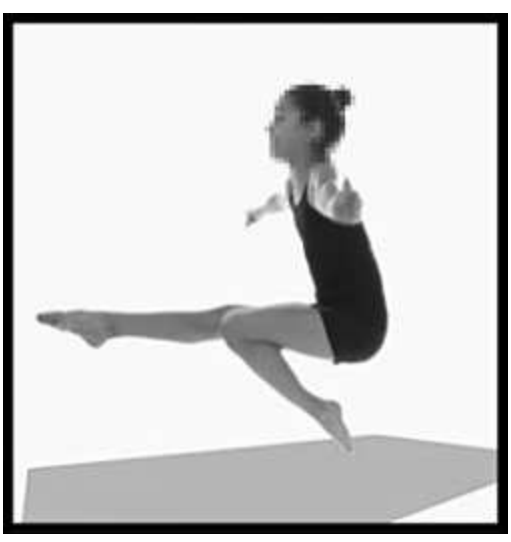

FIGURE 2 - Jump shape corresponding to Tests 2 and 3: Cossack Jump.

\section{Statistical procedures}

The Software Statistical Package for the Social Sciences - Version 18.0 (SPSS Statistics 18.0) was used for statistical the data treatment and the significance level for the rejection of the null hypothesis was set at $\alpha=0.05$ (confidence interval of $95 \%)$.

Initially the exploratory analysis of data was made through normality test of Shapiro-Wilk. After the confirmation of the normality of the distribution ( $p>0.05)$ we proceed to the parametric tests using the $\mathrm{T}$ test for independent samples.

The descriptive statistics were carried out using the mean as measure of central tendency and the standard deviation as dispersion measurement.

For the comparison of the somatic measures between groups, T Test and non-parametric tests Mann-Whitney Test were applied, depending of the verification of the normality distribution.

To compare the explosive power levels of PLL and NPLL of the same gymnast the non-parametric Test - Wilcoxon test was used.

\section{Results}

\section{Measures between groups: High Level (HL) and National Level (NL)}

In TABLE 1 are presented the somatic measures and training characteristics from the two groups.
We can see significant differences between the groups: HL and NL only in variable Number of Trainings/ week, once the HL gymnasts practice 7 days a week and the NL gymnasts practice 5.14 days per week.

TABLE 1 - Descriptive statistics for somatic measures and training characteristics between groups.

${ }^{*} p \leq 0.05$ : significant

\begin{tabular}{lccc}
\hline Somatic measures and training characteristics & High level $(\mathbf{x} \pm \mathbf{s d})$ & National level $(\mathbf{x} \pm \mathbf{s d})$ & Proof value $(\mathbf{p})$ \\
\hline Age (years) & $13.60 \pm 0.245$ & $13.76 \pm 0.194$ & 0.616 \\
Height $(\mathrm{cm})$ & $1.58 \pm 0.007$ & $1.57 \pm 0.113$ & 0.753 \\
Weight $(\mathrm{kg})$ & $41.60 \pm 0.828$ & $44.31 \pm 1.237$ & 0.220 \\
Years of practice (years) & $7.20 \pm 0.490$ & $7.08 \pm 0.356$ & 0.689 \\
N. trainings / week & $7.00 \pm 0.000$ & $5.14 \pm 0.134$ & $0.000^{*}$ \\
N. training hours / day & $3.57 \pm 0.000$ & $3.43 \pm 0.100$ & 0.671 \\
\hline
\end{tabular}

\section{Levels of explosive power in Portuguese junior gymnasts}

In the FIGURE 3, we can observe the mean value and the range of the data of each jump performed by the gymnasts in the study. In general they achieved the best higher average results $(31.6 \mathrm{~cm})$ in the stag jump. As expected, the Cossack jump with PLL forward had a higher average height $(28.8 \mathrm{~cm})$ than the one performed with the NPLL forward $(26.2 \mathrm{~cm})$. 


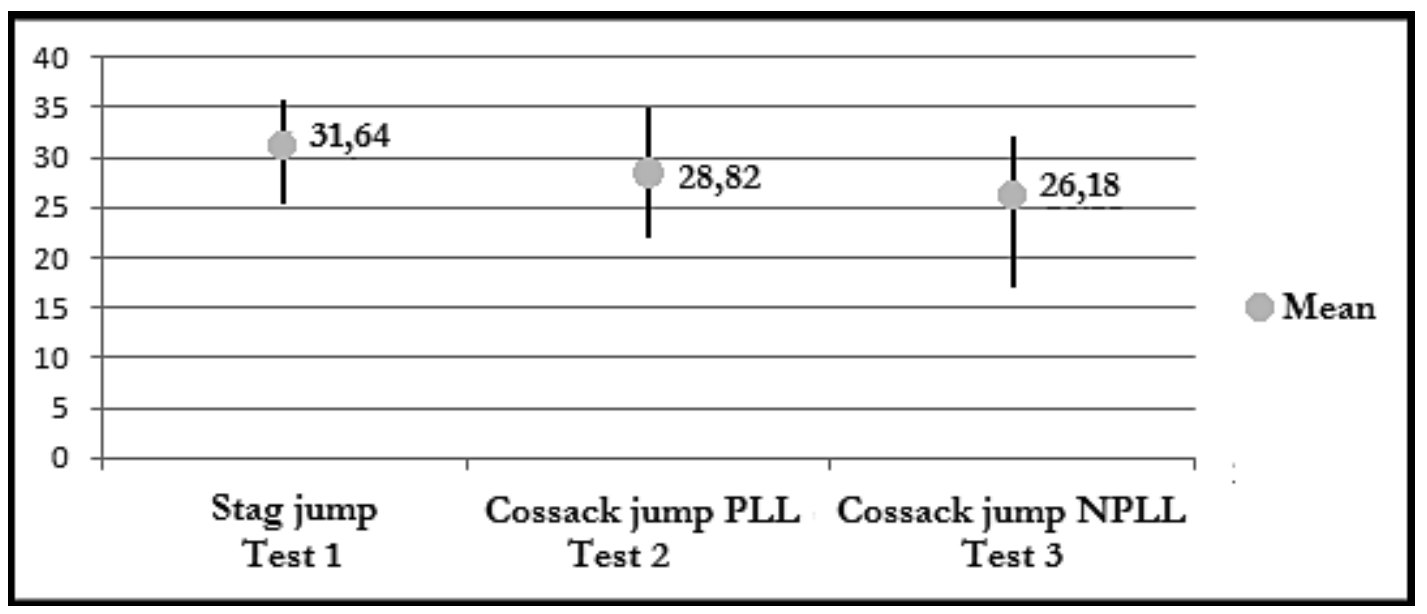

FIGURE 3 - Average results of explosive power test for all gymnasts in the sample.

\section{Comparison Cossack Jump with NPLL and PLL take-off}

In evaluation of Cossack jump (TABLE 2), $86.7 \%$ of the gymnasts jumped higher jump with PLL forward (26 gymnasts) and $13.3 \%$ with the NPLL forward (4 gymnasts).

Therefore is important to identify individually through TABLE 3 the height values reached in the Cossack jump with PLL and NPLL forward reached by the junior gymnasts in order to verify the difference of explosive power between the LL in the tests (Asymmetry Index).
The athletes were classified considering the asymmetry values.

To calculate the Asymmetry Index (AI) between the PLL and NPLL, it was used the difference between these two variables divided by the average between them and multiplied by 100 . This formula (FIGURE 4) was presented by MARCHETTI ${ }^{22}$.

For the differences between LL was used the asymmetry limit considered clinically acceptable in $15 \%{ }^{22}$.

According to the values of Asymmetry Index in TABLE 3, 83.3\% of the gymnasts presented acceptable values for the difference between LL (Asymmetry level lower than 15\%).

TABLE 2 - Explosive power LL, Cossack jump with PLL and NPLL - Output Wilcoxon test.

\begin{tabular}{|c|c|c|c|c|}
\hline & Positive rank ${ }^{* 1}$ & Negative rank ${ }^{* 2}$ & TIES $^{* 3}$ & Proof value (p) \\
\hline Cossack & 26 & 4 & 0 & $0.000^{*}$ \\
\hline
\end{tabular}

$$
\mathrm{AI}=\frac{\text { PLL }- \text { NPLL }}{\text { Average between LL }} \times 100
$$

FIGURE 4 - Formula used to determine the asymmetry index between LL. 
TABLE 3 - Average values individually reached in the evaluation of Cossack jump with PLL and NPLL; Average of the results achieved with both LL and score; Asymmetry Index between LL.

\begin{tabular}{|c|c|c|c|c|}
\hline Gymnast & PLL forward (cm) & NPLL forward (cm) & Average between LL (cm) & Asymmetry level (\%) \\
\hline 1 & $31.9(4)$ & $32.0(2)$ & $32.0(2)$ & $0.3 \%$ \\
\hline 2 & $21.9(30)$ & $22.1(28)$ & $22.0(29)$ & $0.9 \%$ \\
\hline 3 & $27.4(23)$ & $27.0(12)$ & $27.2(20)$ & $1.5 \%$ \\
\hline 4 & $30.3(8)$ & $29.3(5)$ & $29.8(8)$ & $3.4 \%$ \\
\hline 5 & $23.3(28)$ & $22.5(27)$ & $22.9(28)$ & $3.5 \%$ \\
\hline 6 & $25.6(27)$ & $24.5(23)$ & $25.1(26)$ & $4.4 \%$ \\
\hline 7 & $29.4(11)$ & $28.0(9)$ & $28.7(12)$ & $4.9 \%$ \\
\hline 8 & $28.0(21)$ & $26.5(15)$ & $27.3(17)$ & $5.5 \%$ \\
\hline 9 & $28.7(18)$ & $30.4(4)$ & $29.6(9)$ & $5.8 \%$ \\
\hline 10 & $30.8(7)$ & $29.0(7)$ & $29.9(7)$ & $6.0 \%$ \\
\hline 11 & $30.2(9)$ & $28.2(8)$ & $29.2(10)$ & $6.8 \%$ \\
\hline 12 & $31.5(5)$ & $29.3(6)$ & $30.4(5)$ & $7.2 \%$ \\
\hline 13 & $26.6(25)$ & $24.7(22)$ & $25.7(23)$ & $7.4 \%$ \\
\hline 14 & $29.1(17)$ & $26.9(13)$ & $28.0(13)$ & $7.9 \%$ \\
\hline 15 & $26.6(26)$ & $24.4(24)$ & $25.5(24)$ & $8.6 \%$ \\
\hline 16 & $27.8(22)$ & $25.4(20)$ & $26.6(21)$ & $9.0 \%$ \\
\hline 17 & $28.6(19)$ & $25.9(19)$ & $27.3(18)$ & $9.9 \%$ \\
\hline 18 & $29.2(14)$ & $26.2(16)$ & $27.7(15)$ & $10.8 \%$ \\
\hline 19 & $29.2(15)$ & $26.2(17)$ & $27.7(16)$ & $10.8 \%$ \\
\hline 20 & $35.0(1)$ & $30.8(3)$ & $32.9(1)$ & $12.8 \%$ \\
\hline 21 & $28.2(20)$ & 32.1 (1) & $30.2(6)$ & $12.9 \%$ \\
\hline 22 & $27.2(24)$ & $23.8(25)$ & $25.5(25)$ & $13.3 \%$ \\
\hline 23 & $31.1(6)$ & $27.2(11)$ & $29.2(11)$ & $13.4 \%$ \\
\hline 24 & $29.9(10)$ & $26.0(18)$ & $28.0(14)$ & $14.0 \%$ \\
\hline 25 & $29.2(16)$ & $25.3(21)$ & $27.3(19)$ & $14.3 \%$ \\
\hline 26 & $34.3(3)$ & $27.5(10)$ & $30.9(4)$ & $22.0 \%$ \\
\hline 27 & $29.4(12)$ & $22.8(26)$ & $26.1(22)$ & $25.3 \%$ \\
\hline 28 & 34.9 (2) & $26.8(14)$ & 30.9 (3) & $26.3 \%$ \\
\hline 29 & $22.6(29)$ & $17.1(30)$ & $19.9(30)$ & $27.7 \%$ \\
\hline 30 & $29.3(13)$ & $17.6(29)$ & $23.5(27)$ & $49.9 \%$ \\
\hline
\end{tabular}

\section{Levels of explosive power between groups: HL and NL}

The HL and NL gymnasts showed similar results in the height reached in stag jump with 2 feet takeoff (Test 1) and the Cossack jump with the PLL forward (Test 2) (TABLE 4). However, significant differences were found between the groups in the height reached in the Cossack jump with NPLL forward (Test 3). The HL gymnasts presented higher values for the take-off with PLL forward than the NL group. 
TABLE 4 - Average values reached per groups in the evaluation of Stag jump and Cossack jump with PLL and NPLL; Significance Level for the comparison between HL and NL gymnasts in explosive power of LL.

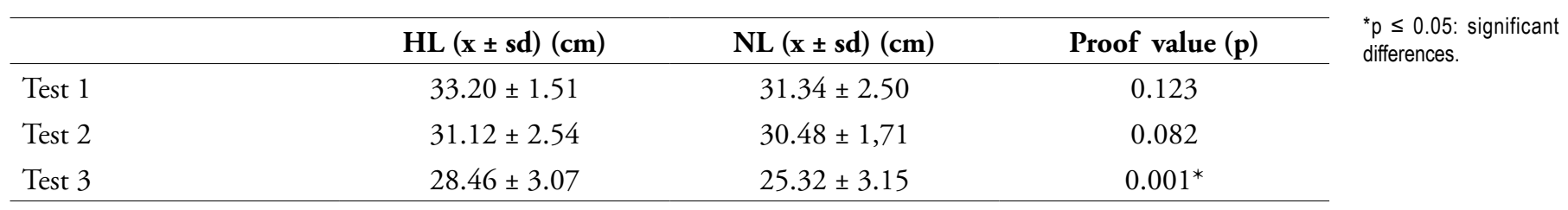

\section{Discussion}

The purpose of this study was to analyze the explosive power of LL for junior gymnasts, with $13.7 \pm 0.17$ years old. The gymnasts had around 7 years of sports experience, and had a sports initiation at 6 and 7 years old.

For LlOBET ${ }^{23}$, the gymnasts should start training explosive power around 7 or 8 years old. The high evolution of this motor capacity starts by 11 and 13 years old ${ }^{23}$. The gymnasts of our sample started the sports activity at the ideal period, between 6 and 8 years old, as stated by RóBEva and RANKÉLOVA ${ }^{24}$.

In the tests of explosive power of LL we analyzed the height of two different jumps of RG, accomplished in countermovement and with movement of upper limbs. In start, the gymnast makes a knee semiflexion and this movement of LL characterizes the countermovement through the lowering of mass centre $^{11}$. The use of upper limbs improves the jump performance, since the arms elevation produces a supplementary force to the take-off ${ }^{1,25-26}$.

The countermovement allied to the upper limbs movement potentiates the vertical jump ${ }^{11,26}$. The jumps studied were all performed with countermovement and upper limbs movement. Therefore, the differences registered between the different jumps were not due to adding the upper limb movement.

$86.7 \%$ of gymnasts presented higher values in stag jump than in Cossack jump. In stag jump the average height was $31.7 \mathrm{~cm}$ and in Cossack jump with PLL forward was $28.9 \mathrm{~cm}$.

MURAD ${ }^{15}$ conducted a research about explosive power of LL with gymnasts aged 11 to 13 years old. They executed a vertical jump in countermovement and reached an average of $26.0 \pm 1.20 \mathrm{~cm}$.

PETRY $^{11}$ evaluated 4 jumps (vertical, vertical with rotation of the body on $360^{\circ}$, stag ring and straddle jump) with countermovement and upper limb movement performed by junior gymnasts aged 13 to 15 years old and concluded that gymnasts with low flexibility levels didn't achieved the jump shape during the flight. The results found were $34.5 \mathrm{~cm}$ for straddle jump; $30.6 \mathrm{~cm}$ for vertical jump; 26.1 $\mathrm{cm}$ for vertical jump with $360^{\circ}$ body rotation and $24.6 \mathrm{~cm}$ for stag ring jump.

Di CAGNo et al. ${ }^{4}$ conducted a research about RG jumps and they observed different values for each type of jump. For the vertical jump the average height was $25.0 \mathrm{~cm}$ and $24.0 \mathrm{~cm}$ for Cossack jump with $180^{\circ}$ rotation. For the leaps the average was $27.0 \mathrm{~cm}$ for Enjambée, $24.0 \mathrm{~cm}$ for Cossack jump with $180^{\circ}$ rotation and $18.0 \mathrm{~cm}$ for the Jeté en Tournant.

As in Petry ${ }^{11}$ and Di Cagno et al. ${ }^{4}$ the jumps studied were different which justifies the different values observed for the flight height..

The gymnast jumping capacity depends on her quick strength quality, flexibility and also the technique master to perform the movement ${ }^{14}$. The jumps evaluated in this study, are considered accessible to perform and do not require a stressed range of thigh-femoral articulation to be performed correctly ${ }^{13}$, therefore, the values obtained would depend on LL muscle power.

According to the observations done during the tests we believe that the gymnasts did not reach higher values on the height of the Cossack jump because for them it was difficult to elevate the flexed LL until the horizontal, as execute with a correct technique described by RG Code of Points ${ }^{27}$. Meanwhile in the stag jump the gymnasts did not found any execution problem.

When we compare the results of the explosive power reached at Cossack jump with PLL and NPLL, as expected, we found significant differences between the 2 jumps. However only $16.6 \%$ of gymnasts presented an asymmetry index in the takeoff between the LL superior to the limit considered as acceptable in $15 \%$ according to MARCHETti ${ }^{22}$.

The preference for one limb can be justified by laterality, which SALADINI et al. ${ }^{28}$ defines as the tendency to use preferably one side of the body to 
the important efforts. Furthermore these authors added that the predominant side is characterized by a higher level muscle power, higher speed and greater precision.

DiAs $^{29}$ explains that the gymnast's motor experience can strengthen the preference for one side of the body or, through a bilateral training, it can decrease the preference strength and make it equal in both sides of the body. Cobalchini and Silva ${ }^{30}$ corroborate this statement considering that the NPLL may present similar performance to the PLL when this is correctly stimulated. And Lisitskaya ${ }^{14}$ advised for the use in some training sessions, a high proportion of movements with the NPLL, because the dominant side as well as the non-dominant is essential to the practice of $R G^{31}$.

Regarding the definition of PLL we found disagreements in the literature reviewed. $\mathrm{MACHO}^{32}$ conducted a research about bilateral asymmetry and conclude that the NPLL was stronger and heavier because it's the support limb while the PLL performs other movements. For SchleIP ${ }^{33}$, the PLL has tendency to be stronger, performs larger steps during walking and presents itself in a slightly minor shape. This author considers this characteristic as normal, by the tendency of an increasing to burden the PLL with the body weight, contributing to its shortening.

In this study, to perform the Cossack jump, we considered the PLL forward and the NPLL is the last one to leave the ground, flexed during jump. In this case the NPLL performing the step must present enough strength to impulse the body to move upwards.

We observed that $86.7 \%$ of gymnasts registered higher values for jump height when it was performed with PLL forward and only $13.3 \%$ of gymnasts when the jumps was performed with the NPLL forward. These values may be explained by the fact that the athletes intensively used the NPLL during training sessions as the support member in the most part of the movement and body elements since an early age. However the warm up and the specific preparation should be organized respecting the principles of laterality.

When we compare the results of LL explosion power between groups (HL and NL) we found that the national team gymnasts had higher results in NPLL Cossack jump forward (Test 3) only, and similar results in stag jump (Test 1) and PLL Cossack jump forward (Test 2).

The HL group had $1.58 \mathrm{~m} \pm 0.01$ height and 41.6 $\mathrm{kg} \pm 0.83$ of weight. The NL had $1.57 \mathrm{~m} \pm 0.11$ height and $44.3 \mathrm{~kg} \pm 1.24$ of weight. The differences aren't considered significant and therefore, these data have no influence in the results of the tests.

Petry ${ }^{11}$ analyzed the height of four jumps performed by junior gymnasts and for the somatic measurements found that they were average 13.3 years old and height $1.54 \mathrm{~m}$. In this research there were no particular attention to athletes' weight and we consider that this variable is relevant because the evaluation was made only to jumps and the athletes' weight could influence considerably the results achieved.

Considering the other variables analyzed in this study, we verified that the years of practice and number of daily hours of training were, in average, similar values between the HL and NL gymnasts. However, the days of training per week had a significant difference between the two groups of the sample. The HL gymnasts work $3.57 \mathrm{~h}$ per training session and 7 days a week, while the NL gymnasts work $3.43 \mathrm{~h}$ per day, 5.14 days per week. We did not found significant differences in the training duration, but the HL gymnasts have in an additional of $7.36 \mathrm{~h}$ training per week. At the end of each month it is equivalent to 32 hours of practice which can make a huge difference.

Therefore, the higher results of LL explosive power in the HL gymnasts comparing to the NL gymnasts are, probably due to higher duration of the weekly training, to the duration and intensity of the training sessions and finally to the intrinsic genetic factors of the gymnasts bellowing to the HL group, or all these factors together.

According the hypothesis of the study, it was expected that the HL gymnasts had superior level of explosive power than the gymnasts of the NL group. However, the HL group achieved superior marks only in one of the tests (Cossack jump with NPLL forward). Therefore, we can conclude that the gymnasts of the HL group did not show the expected superiority in the tests.

Furthermore, we checked that $83.3 \%$ of the junior gymnasts did not present significant differences at explosive power levels between the PLL and NPLL, which is a positive sign to the work developed with these gymnasts. We conclude that the most of gymnasts observed presented a harmonious development of explosive power for both lower limbs, since they did not show functional asymmetries.

This study had limitations as the reduced number of gymnasts in HL group, but they are the total amount of gymnasts representing their country in international junior competitions in the concerned season. 


\section{Resumo}

Força explosiva de membros inferiores em ginastas da ginástica rítmica de diferentes níveis competitivos

A força na Ginástica Rítmica manifesta-se na grande maioria dos movimentos e elementos realizados pelas ginastas, especialmente nos saltos, que são elementos corporais indispensáveis na prática da modalidade. 0 treino voltado para o desenvolvimento da habilidade de salto apresenta uma grande quantidade de exercícios que visam aumentar o grau de potência muscular de membros inferiores, e portanto, a capacidade de impulsão. A impulsão vertical é uma importante medida utilizada para mensurar a força explosiva de membros inferiores e está diretamente ligada ao sucesso que a ginasta poderá atingir. Deste modo, o presente estudo teve por objetivo avaliar a altura de dois saltos da Ginástica Rítmica (salto de corça e salto cossaco) através da plataforma de contato Ergojump, que calcula a altura do salto em função do tempo de voo, executados por ginastas juniores de nivel nacional e comparar com resultados da Seleção Nacional Júnior - no total 30 ginastas, com idade média de 13,73 $\pm 0,17$ anos. Além disso, comparar os niveis de força explosiva do membro inferior preferido (MIP) e membro inferior não preferido (MINP) de todas as ginastas do estudo, de modo a verificar possiveis assimetrias funcionais. Para a análise estatística recorremos aos Testes Paramétricos (Teste T) e não Paramétricos (Teste Mann-Whitney e Wilcoxon). As ginastas da Seleção Nacional alcançaram melhores resultados em 33\% dos testes, deste modo concluímos que não conseguiram mostrar a superioridade esperada nos testes realizados. Além disso, verificamos que a maior parte das ginastas apresentaram um harmonioso desenvolvimento da força explosiva em ambos os membros inferiores, dado que e $83,3 \%$ das ginastas da amostra não demonstraram assimetrias funcionais.

Palavras-chave: Força explosiva; Saltos; Impulsão vertical; Ginástica ritmica; Membros inferiores.

\section{References}

1. Jastrjembskaia N, Titov Y. Rhythmic gymnastics: hoop, ball, clubs, ribbon, rope. Champaign: Human Kinectics; 1999.

2. Sousa FMAM. Biomecânica dos saltos em ginástica rítmica desportiva: análise cinemática e caracterização técnica dos principais saltos em ginástica rítmica desportiva [dissertação]. Porto(PT): Universidade do Porto, Faculdade de Ciências do Desporto e de Educação Física; 1997.

3. Silva MRAG. Alteraçôes induzidas pelo novo código de pontuação no treino de força em ginástica rítmica [monografia]. Porto(PT): Universidade do Porto, Faculdade de Ciências do Desporto e de Educaçáo Física; 2001.

4. Di Cagno A, Baldari C, Battaglia C, et al. Leaping ability and body composition in rhythmic gymnasts for talent identification. J Sports Med Phys Fit. 2008;48:341-6.

5. Badillo JJG, Ayestáran GE. Fundamentos do treinamento de força: aplicaçáo ao alto rendimento desportivo. Porto Alegre: Artmed; 2001.

6. Bobo M, Sierra E. Ximnasia rítmica deportiva: adestramento e competición. Santiago de Compostela: Lea; 1998.

7. Douda H, Tokmakidis S, Tsigilis N. Effects of specific training o muscle strength and flexibility of sports and artistic female gymnasts. Coach Sport Sci J. 2002;4:23-7.

8. Laffranchi B. Treinamento desportivo aplicado à ginástica rítmica. Londrina: UNOPAR; 2001.

9. Despina T, George D, George T, et al. Short-term effect of whole-body vibration training on balance, flexibility and lower limb explosive strength in elite rhythmic gymnasts Hum Mov Sci. 2014;33:149-58.

10. Kraemer WJ, Newton RU. Training for improved vertical jump. Sports Sci Exch. 1994;7:1-12.

11. Petry R. Análise do deslocamento vertical de quatro saltos realizados por praticantes de ginástica rítmica em diferentes fases do treinamento [dissertação]. Florianópolis(SC): Universidade do Estado de Santa Catarina, Centro de Ciências da Saúde e Esporte; 2008.

12. Fédération International de Gymnastique. Rhythmic gymnastcs: code of points 2013-2016. Lausanne: FIG; 2012.

13. Lebre E, Araújo C. Manual de ginástica rítmica. Porto: Porto Editora; 2006.

14. Lisitskaya T. Gimnasia rítmica. deporte \& entrenamiento. Barcelona: Editorial Paidotribo; 1995.

15. Murad VC. Análise da força explosiva de membros inferiores em atletas de ginástica rítmica e ginástica artística feminina [monografia]. Porto Alegre(RS): Universidade Federal do Rio Grande do Sul, Escola de Educação Física; 2009. 
16. Piazza M, Battaglia C, Fiorilli G, et al. Effects of resistance training on jumping performance in pre-adolescent rhythmic gymnasts: a randomized controlled study. Ital J Anat Embryol. 2014;119:10-9.

17. Ugrinowitsch C, Barbanti VJ, Gonçalves A, Peres BA. Capacidade dos testes isocinéticos em predizer a "performance" no salto vertical em jogadores de voleibol. Rev Paul Educ Fís. 2000;14:172-83.

18. Federation International de Gymnastique. Rhythmic gymnastcs: code of points 2009-2012. Lausanne: FIG; 2009.

19. Galdino LAS, Nogueira CJ, César EP, Fortes MEP, Perrout JR, Dantas EHM. Comparação entre níveis de força explosiva de membros inferiores antes e após flexionamento Passivo. Fit Perform J. 2005;4:11-5.

20. Szmuchrowski LA, Vidigal JM. Saltos nos diagnósticos e prescrição das cargas de treinamento. João Pessoa: Universitária; 1999.

21. Federation International de Gymnastique. Rhythmic gymnastcs: code of points 2009-2012. Lausanne: FIG; 2009.

22. Marchetti PH. Investigaçóes sobre o controle motor e postural nas assimetrias em membros inferiores [tese]. São Paulo(SP): Universidade de São Paulo, Escola de Educação Física e Esporte; 2009.

23. Llobet AC. Gimnasia rítmica deportiva: teoria y práctica. 3a ed. Barcelona: Editorial Paidotribo; 2000.

24. Róbeva N, Rankélova M. Escola de campeãs: ginástica rítmica desportiva. São Paulo: Ícone; 1991.

25. Devisa DS, Briscoeb DA, Markowiski CT, Savilled SE, Taylore CJ. Physical characteristics that predict vertical jump performance in recreational male athletes. Phys Ther Sport. 2003;4:167-74.

26. Galdi EHG. Pesquisas com salto vertical: uma revisão. Rev Treinam Desportivo. 2000;5:51-61.

27. Fédération International de Gymnastique. Rhythmic gymnastcs: code of points 2013-2016. Lausanne: FIG; 2012.

28. Saladini AC, Fogaça OMJ, Reis PF. Saberes sobre o conteúdo dominância lateral: contribuiçóes para a educação física. $23^{\circ}$ Congresso Internacional de Educação Física; 2012; Foz do Iguaçu, BR. Foz do Iguaçu: FIEP; 2010.

29. Dias HF. Efeito da experiência motora e da idade sobre a lateralidade em escolares [monografia]. Londrina(PR): Universidade Estadual de Londrina; 2010.

30. Cobalchini R, Silva ER. Treinabilidade do membro inferior não-dominante em atletas infantis de futebol. Lect Educ Fís Deportes. 2008;13. Available from: http://www.efdeportes.com/efd125/treinabilidade-do-membro-inferior-nao-dominante-em-atletas-infantis-de-futebol.htm.

31. Giolo C. Noção de lateralidade: um estudo diagnóstico com ginastas iniciantes [monografia]. Campinas(SP): Universidade Estadual de Campinas, Faculdade de Educaçáo Física; 2008.

32. Macho G. Anthropological evaluation of left-right differences in the femur of Southern African populations. Anthropologischer Anzeiger. 1991;49:207-16.

33. Schleip R. The dominant leg: summary of an article by Simone Kosog in the science section of the 'Süddeutsche Zeitung Magazin’ 1999 [cited 6 Apr 2011]. Available from: http://www.somatics.de/DominantLeg.htm.

\section{Acknowledgements}

The authors would like to thanks the gymnasts and their coaches for taking part in this study.

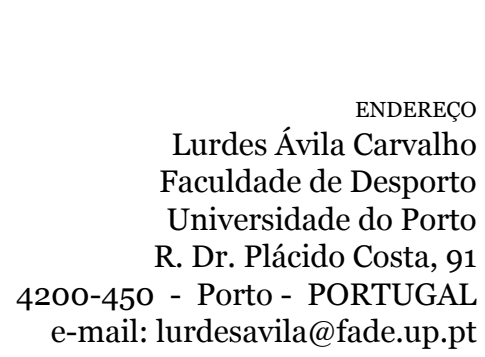

Recebido para publicação: 26/10/2015

Aceito: 01/12/2015

50 • Rev Bras Educ Fís Esporte, (São Paulo) 2016 Jan-Mar; 30(1):41-50 